\title{
Climate Change and Underwater Technology
}

\author{
Khalidullin 0* \\ Ecology Professor, Academician of the Kazakh National University, Kazakhstan \\ *Corresponding Author: Khalidullin O., Ecology Professor, Academician of the \\ Kazakh National University, Kazakhstan.
}

Received: November 06, 2020

Published: March 23, 2021

(C) All rights are reserved by Khalidullin $\mathbf{0 .}$
The rise in natural disasters is a warning, a reminder to humanity about climate change. The change was not easy. For millions of years, water, biota (a single community of plants and animals) and the water cycle have been created and improved in a single system. One of the elements of the biota - man - mastered and enslaved water, destroying most of the rest of the biota on 70 percent of the land. The scale of expansion went far beyond the limits allowed by nature. Man created a new phenomenon - artificial evaporation, which destroyed the water cycle between the atmosphere and the soil. The developing imbalance changes the dynamic balance of the interaction between water, biota and the water cycle. More details: https://actascientific.com/ASBT/pdf/ASBT-01-0067.pdf.

Water must dissolve minerals in itself, deliver them to plant roots and animals, and leave them in a new quality. These links in the chain of circulation are not taken into account by humanity. Therefore, the number of plants and animals on the planet has decreased with the degradation of territories. It is important to understand here that we took 70 percent of the land from the biota by arable land, landfills, and asphalt. The destruction of biota on these lands leads to a change in the quality of moisture released into the atmosphere. From the degraded land, rainwater evaporates unchanged - this is artificial evaporation.

The second important element of anthropogenic impact on the climate is the withdrawal of water from natural sources. There was no heating and cooling of water in nature, its transportation through pipes, canals, irrigation of monocultures, and many other processes created by modern technologies. According to informa- tion from http://www.erudition.ru/referat/ref/id.48920_1.html it is known that every year people take about 2000 cubic meters from rivers and lakes. kilometers of fresh water, which is about $5 \%$ of the flow of all rivers in the world. She is driven through pipes and canals, watering monocultures, washing and drying everything that surrounds us and ourselves. Everything that evaporates after such use - from technological processes, evaporators and coolers of power plants, from sewage tanks, from towels, wet plates - evaporates into the atmosphere without natural changes. They are also called artificial vapors.

The third significant source of artificial evaporation is flood spills. Each outlet of water from the channels is accompanied by spills with flooding of vast areas. These are new volumes of water evaporation that does not fulfill its natural functions.

Flood reduction is necessary not only to save lives and reduce destruction, but also to reduce artificial evaporation - a strategically important aspect of stopping climate change.

Considering the causes of floods, it can be seen that rivers are continuously raising the level of their bottom sediments. The main part of the new sediments is made up of coastal erosion in the course of its natural meandering - coastal erosion. But mankind has significantly increased the sediment by adding its own waste from coastal settlements. The outflow of water from the banks occurs mainly due to underwater dams - rifts. They are invisible from land, but the carrying capacity of rivers decreases as they flow inside and below cities and towns. 
If these underwater dams are removed, then the outflow of water from the banks will move downstream, outside the settlements. Then it is possible to avoid destruction in places undesirable for humans. But to reduce artificial evaporation, it is necessary to eliminate floods altogether. To do this, it is necessary to deepen and regulate the movement of river waters constantly and to prevent overflowing the banks.

Existing dredging technologies are based on excavation, bulldozing, suction and dredging with serial equipment with pollution of coastal areas and, incredibly, large financial and material costs. Not every offshore business can afford these costs.

Can't you use the forces of the river itself to profile your own bed. If its energy can destroy banks, houses, roads during floods, then, probably, you can use these forces for your own improvement.

There are known innovations that use the forces of the river to form the river bed within the specified limits, with the specified depths for the passage of ships, control of water flows. The manufacture and operation of such products are so simple that they are available to small coastal farms that suffer from floods, coastal collapse, and shallowing of fairways (Figure 1).

Eurasian (21) (13) Patent Office (12) description of the invention to the Eurasian application (43) application of Khalidullin O. Kh. (KZ). https://easpatents.com/5-18312-sposob-ochistki-iuglubleniya-rusel-rek-ot-donnyh-otlozhenijj-i-ustrojjstvo-dlyaego-osushhestvleniya.html.

Method for cleaning and deepening river beds from sediments and equipment for its implementation.

The invention relates to hydraulic engineering and can be used to clean river beds and canals from sediments. In the method of cleaning and deepening river beds from bottom sediments, a concentrated flow in The holes are directed to the bottom and forming erosion and alluvial zones, change the bottom profile. The device moves along the river bed and washes away sediments. The hardened part of bottom sediments is destroyed by the mechanical action of additional devices located on the device. The concentration of the water flow is ensured by the bottom of the device and the tapered side walls pressed against the bottom of the river. The device constructively uses the flow of the river and requires little energy to move.
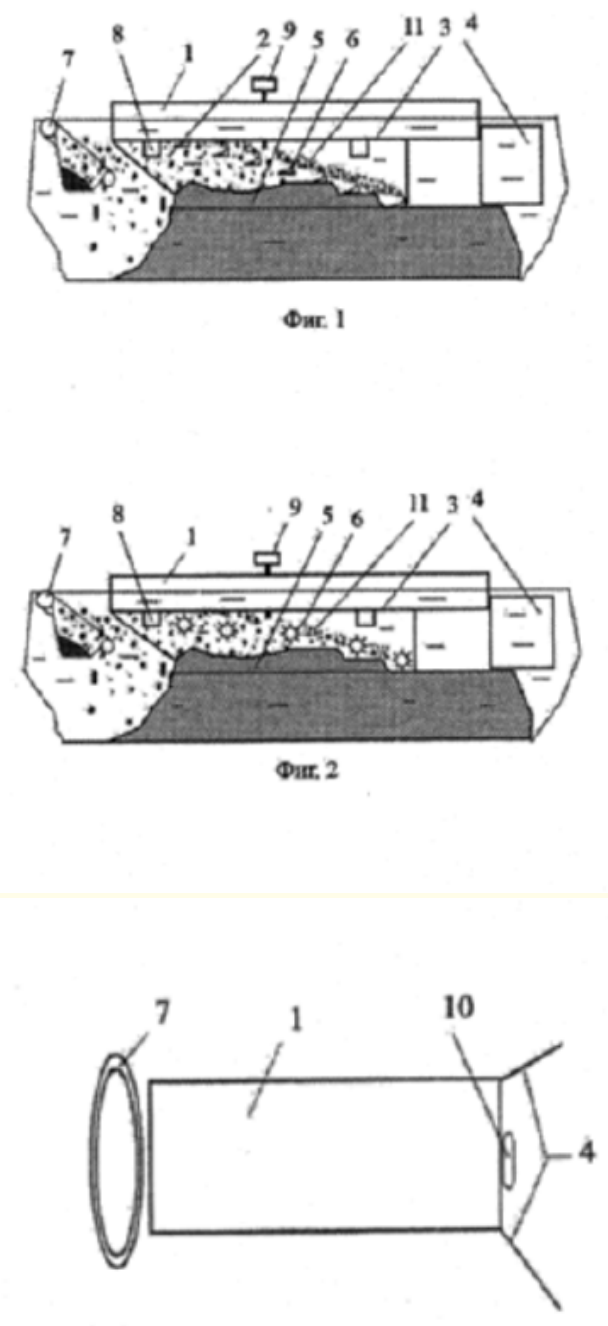

Фur. 3

Figure 1: Device for deepening the bottom.

The technological process is carried out by directing a part of the stream to pre-selected places of the channel. Zones of erosion and alluvium are created - sedimentation of bottom sediments, which develop and move in specified sizes and directions. Depending on the parameters of the river and the design, the devices are controlled from the bank with cables or supplemented with means 
of independent movement. The device must stand firmly on the bottom and control the flow of water. It can be equipped with a variety of mechanisms for changing the buoyancy and windage for movement with the flow. More functional and productive devices are equipped with lead screws driven by their own power plant. This is necessary for free movement under water and on the water surface.

Supplementing the device with an underwater life support cabin and serial devices for hydraulic engineering work allows the creation of an absolutely new technology for underwater operations. In addition to dredging, it becomes possible to search for and retrieve sunken objects, use any underwater equipment - pumps and openers, cranes and other mechanisms for cutting surface and sunken tree trunks, washing and sorting bottom sediments, for example, for gold mining without lifting waste rock to the surface... The impact on the bottom of the controlled current does not negatively affect the bottom fauna, like the famous dredges and all other known dredging machines.

Tests of individual elements of micro-models of the proposed device have been carried out on small rivers, but this is not enough for full-scale research and creation of a new technology. R\&D and testing required.

A positive first experience at a natural site will make it possible to start a universal simultaneous deepening of the bottom of all rivers where floods occur and to prevent them in the near future. The design of such devices and their low cost will allow their rapid distribution. The types of devices are developed for each type of water body. From small to great rivers such as the Nile, Ural, Mississippi, Yangtze and Amazon.

To save water for the summer period, it is customary to build reservoirs on the basis of large dams. Practice shows that abnormal precipitation leads to the breakthrough of such dams and manmade floods. The reasons leading to this also lie in the prolonged sedimentation of the reservoir itself by river sediments. Periodically, it is necessary to clean the reservoir from deposits. Here the shown principle of cleaning the river bed by the proposed method can be applied. The propeller can be turned into a flow propeller and used to create a watercourse in slow flowing rivers and even in stagnant bodies of water. In fact, a completely new underwater vehicle is proposed that moves along the bottom of the reservoir and performs hydraulic engineering work. And if we supplement it with a caterpillar drive, then it becomes an amphibious vehicle that goes on land (Figure 2).

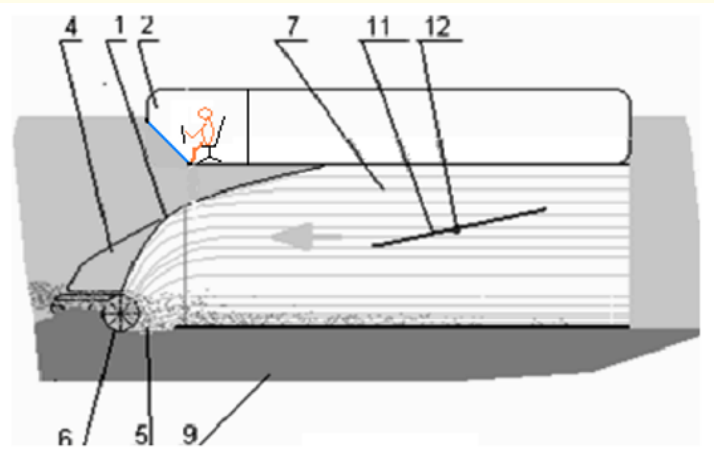

Figure 2: New underwater vehicle.

We offer cooperation to manufacturers of dredging equipment, offshore enterprises, investors, all interested parties.

\section{Assets from publication with us}

- Prompt Acknowledgement after receiving the article

- Thorough Double blinded peer review

- Rapid Publication

- Issue of Publication Certificate

- High visibility of your Published work

Website: www.actascientific.com/

Submit Article: www.actascientific.com/submission.php Email us: editor@actascientific.com

Contact us: +919182824667 